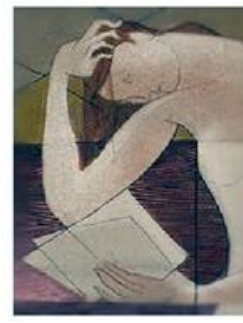

\title{
Os anos de formação de Antonio Candido: livros como forma de vida
}

\author{
The Formative Years of Antonio Candido: Books as a Way of Life
}

\begin{abstract}
Atilio Bergamini ${ }^{1}$
Resumo: Este ensaio reconstrói os anos de formação de Antonio Candido a partir das memórias do crítico literário adulto a respeito da biblioteca dos seus pais. O ensaio busca também ser uma despretensiosa introdução a algumas ideias de Candido.
\end{abstract}

Palavras-chave: Antonio Candido; História da Leitura; Memória.

Abstract: This essay reconstructs Antonio Candido's formative years, emphasizing Candido's memories of his parents' library. The essay also seeks to be an unpretentious introduction to some of Candido's ideas.

Keywords: Antonio Candido; History of Reading; Memory.

Porque há outros que se formam por outras vias: a técnica, a ciência, o esporte, a ação econômica, a aventura. Mas o que desejo é traçar o contorno de um tipo peculiar: o do menino que lê e ama a leitura como uma forma de vida. Que vive em grande parte através dos seus livros. (Antonio Candido, depoimento dado à União Brasileira dos Estudantes em 1984)

Para Adelaide Gonçalves

\section{Paixão do concreto}

Era 1967. No prefácio que escreveu para o que viria a ser a quinta edição das Raízes do Brasil, de Sergio Buarque de Holanda, Antonio Candido assinalou:

A certa altura da vida, vai ficando possível dar balanço no passado sem cair em autocomplacência, porque o nosso testemunho se torna registro da experiência de muitos, de todos que, pertencendo ao que se chama uma geração, julgam-se a princípio diferentes uns dos outros, mas vão aos poucos ficando tão iguais que acabam desaparecendo como indivíduos para se dissolverem nas características gerais da sua época. (CANDIDO, 2007a, p. 125)

Teria havido uma geração, com mais ou menos cinquenta anos naquela época, que aprendera a refletir e se interessar pelo Brasil lendo três grandes interpretações, além de Raízes (1936), também Casa-grande e senzala (1933), de Gilberto Freyre, e Formação do Brasil contemporâneo (1943), de Caio Prado Jr. De Caio, aquela geração também apreciava o

\footnotetext{
${ }^{1}$ Professor do Departamento de Literatura da Universidade Federal do Ceará e do Programa de Pós-Graduação em Letras da Universidade Federal do Ceará.
} 


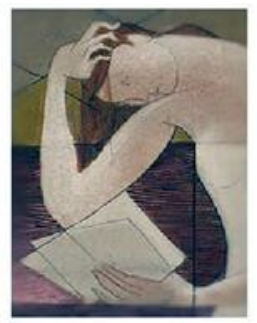

"livrinho", como chamavam Evolução política do Brasil (1933). Candido disse em uma entrevista que leu o livrinho em 1935, ainda em Poços de Caldas.

\begin{abstract}
[M] deu a impressão de estar revendo o Brasil de um ângulo novo. Eu já tinha algumas leituras históricas e lera no ano anterior com grande apreço Populações meridionais do Brasil, de Oliveira Vianna. A visão de Caio me abalou, inclusive pela sobriedade e o tom convicto da exposição. Depois de tanto tempo eu não saberia pormenorizar as impressões. Lembro do impacto causado pela utilização do conceito de luta de classes desde a Colônia, sobretudo na análise das rebeliões do tempo da Regência e começo do Segundo Reinado, que nos meus compêndios eram tratados como meros episódios de desordem. (PRADO JR., 2012, p. 278)
\end{abstract}

Testemunhar sobre a leitura de um livro, sobre si como aprendiz das formações do Brasil, era, quem sabe, abordar as "características gerais da época" ou, como diria Candido ao escrever sobre Otto Maria Carpeaux, de "uma cultura mental transformada em bem comum" (Recortes, p. 100). Aqui se define um traço da visão de mundo de Candido: seria possível conhecer uma sociedade lendo atentamente as "estruturas" ficcionais e ensaísticas presentes nela. Ir fundo em um texto equivaleria a ir fundo em um problema social mediado pela visão de mundo estruturada em uma obra e, assim, "ver a sociedade do ângulo da literatura e a literatura do ângulo da sociedade, sem paralelismo mecânico, mas de um modo orgânico e vivo" (CANDIDO, 2018, p. 67). As leis do mundo produzido por cada obra de arte permitem produzir uma visão crítica potente sobre as leis do mundo social, às quais as leis artísticas não remetem imediatamente. A relação entre os dois processos é a imaginação radical do leitor crítico.

Intelectuais como Carpeaux, de acordo com Candido, fariam sínteses que orientavam o leitor num movimento de conjunto produzido pela presença viva de autores e obras. Ao contrário de Carpeaux, porém, que assinala o universal como "espírito objetivo" efetivado em diversos particulares, Candido preferiu na maior parte das vezes iniciar suas pesquisas e exposições desde o particular, isto é, a leitura de textos literários, e, pouco a pouco, quando fosse o caso, por meio de um trabalho de sínteses agregadoras, chegar às tendências do período, aos temas comuns, às características gerais de uma época. A essa atitude ele denominou "paixão do concreto", expressão na qual ecoa "A força do concreto", título de um ensaio seu a respeito de Caio Prado Jr. A proposta de Candido seria, então, que as formas de escrita quando interrogadas de determinadas maneiras - a partir de suas estruturas "internas" - dariam a ver “aspectos fundamentais da sociedade" (CANDIDO, 2018, p. 193).

Portanto, um testemunho de leitura poderia dizer algo da experiência de muitos e, nesse sentido, ganharia amplitude, por mais simples que tenham sido a vida, o trabalho ou as ocasiões 


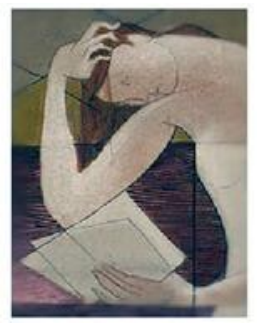

testemunhadas, em que alguém defendeu uma causa. Uma vida é sempre muitas vidas, um livro é sempre muitas vidas.

Em artigo de jornal publicado 1958, Candido considera o testemunho das missivas bem curtinhas que um soldado do fronte da guerra no Paraguai enviava para seus familiares. Esse testemunho ajudou a compreender um pouco da própria guerra e também de como se inoculava o sentimento nacionalista e militarista nos jovens corpos masculinos de então. "A menor palavra, o gesto mais frágil com que sulcamos a vida podem adquirir significado conforme a parábola que ela [a vida] descreve: escritas por quem ia morrer, estas cartas são estacas que levam cada vez mais perto da noite" (CANDIDO, 2008, p. 116).

Isso importa em dizer que Candido abriu a teoria da literatura brasileira para que considerasse qualquer palavra "com que sulcamos a vida". Se nos gestos e nos escritos das assim chamadas pessoas comuns estaria a chave para reflexões a respeito da sociedade, a crítica literária de Antonio Candido seria uma espécie de passo inicial para a reflexão epistemológica em parte do campo das ciências humanas contemporâneas voltada às vidas subalternas, periféricas, racializadas, vulneráveis.

O autor se ocupou em diversas oportunidades de contar a história dessas pessoas simples: gestos e palavras singelos impregnados pelos conflitos do tempo. Entre os inúmeros textos dele soprados por esse intuito, há dois mais longos: Teresina e os seus amigos e Um funcionário da monarquia: ensaio sobre o segundo escalão.

O primeiro narra a história de uma socialista italiana com simpatias anarquistas, a Teresina, muito leitora e estudiosa, que viveu em Poços de Caldas entre 1931 e 1951, tendo dado aulas do seu idioma materno e da cultura de seu país para Antonio Candido; já Um funcionário narra a história de seu bisavô por parte de mãe, Nicolau Tolentino, que parece encarnar a ascensão de ideais radicais de esforço e trabalho contra os privilégios no âmbito estatal brasileiro durante o século XIX.

Não seria de todo disparatado, embora seja outra coisa, incluir nesse viés do pensamento de Candido Os parceiros do Rio Bonito, obra em que pesquisou os caipiras e seu possível desaparecimento, a perda, um tanto brusca, dos utensílios feitos em casa, do conhecimento sobre elaboração de pólvora, da capacidade de fabricar lampiões abastecidos por azeite de mamona, da habilidade de fazer açúcar, rapadura e boa garapa - a boa garapa alienada numa detestável caninha industrializada -, além das moendas, fornos e outros instrumentos úteis para 


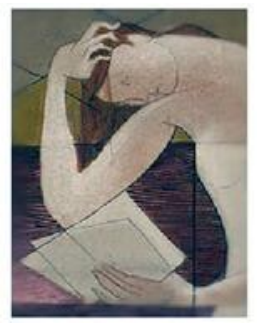

a manutenção da vida; a perda da terra, das sementes, a perda, de uma hora para a outra, pela pressão dos latifúndios e das cidades, desses conhecimentos todos e de laços de solidariedade. Uma época de mudança para pior.

Candido elegeu tom de - utilizo suas palavras - carinho e apreço para narrar os esforços dos que foram seus amigos, convivas ou das pessoas simples, quase esquecidas, pelas quais sentia irmandade. Ele foi de uma insistência dialeticamente discreta e ostensiva nesse ponto: algo em torno de $1 / 3$ dos títulos que publicou em livro - talvez até mais - é pensável como "testemunhos" ou "digressões sentimentais", como o próprio Candido talvez preferisse.

“Se me for permitida uma recordação pessoal"... Lá pelas tantas, em suas palestras e ensaios, ele pedia licença: e falava, com o intuito de testemunhar o século que vivera, o cinema mudo, o cinema falado, a literatura, Poços de Caldas, a vida em São Paulo, a Confeitaria Vienense e a patota de amigos que ia lá para prosear, a revista Clima, Oswáld com acento no á, o PSB, a USP, a ditadura Vargas, a ditadura militar, o fascismo, os colegas professores e assim por diante, conforme o método de assunto-puxa-assunto que, isso também, ele apreciava no modo de escrever e falar de alguns dos seus amigos e conhecidos, atitude lá seu tanto caipira, quem sabe.

Ricardo Piglia argumentou que a crítica literária constituía uma das formas modernas da autobiografia (PIGLIA, 2004, p. 117). Nada mais correto quando pensamos em Antonio Candido. Suas digressões sentimentais são movimentos em que ele se vê como uma das pessoas comuns que se perdem no todo do seu tempo, entre amigos, influências, sonhos e equívocos comungados por muitos e muitas. São movimentos em que ele escolheu um tipo de registro considerado de menor valor em relação ao registro ficcional, que, no Brasil, Machado, Mário, Guimarães e alguns poucos teriam alcançado. Em relação à desses autores, a dele seria uma prosa menor. Pelo sim, pelo não, foi um gênero literário novo, ao qual Candido se dedicou durante décadas, burilando um estilo singular, composto talvez de sugestões colhidas na prosa memorialista de um Pedro Nava, de um Carlos Drummond de Andrade, bem como no lirismo de homenagem deste, que se inaugura com "Ode ao cinquentenário do poeta brasileiro" e vai se desdobrando em poemas para Charles Chaplin, Homero Homem, entre outros tantos, não esquecendo de "Esboço de figura", homenagem ao próprio Candido. Então, o que vou fazer aqui seria mais ou menos apresentar um Antonio Candido por ele mesmo. Ou ainda fazer um "fichário comentado" dos momentos de sua obra em ele fala de si mesmo. 


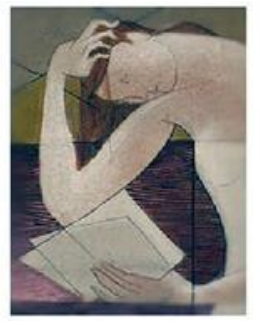

Não tenho preocupação em discutir criticamente cada testemunho, embora fosse de bom aviso ao menos sopesar as diferenças de gênero em que aparecem - palestras, ensaios, prefácios, evocações, cartas - e de período em que foram escritos. Isso tudo tornaria o ensaio mais longo, dando-lhe um jeitão de paper, complicando-o com a desvantagem de um ponto de vista externo, pretensamente capaz de avaliar com distanciamento as escolhas de certo problemáticas feitas por Candido no calor da hora. É certo, como não?, que Candido tenha lembrado fatos de modo truncado, que tenha sido seu tanto etnocêntrico, enfim, ele mesmo faz essas ressalvas. "Se a memória não me falha"... E a memória - com o perdão do acacianismo - não faz outra coisa do que falhar. Que Candido fale sobre si e falhe sobre si: é um bom começo. Que, com sorte, eu o escute e, nisso, alguma leitora, algum leitor também se aprume a escutá-lo.

O tom de carinho e apreço pelo personagem é também uma necessidade pois comparte uma tradição de escritores populares que a obra de Candido ajuda a melhor compreender: Maria Firmina dos Reis e o discurso indireto livre utilizado de maneira inovadora para colar amorosamente o narrador em certos personagens do romance Úrsula de 1858; Carolina Maria de Jesus e a inscrição do cotidiano do século $X X$ - por meio da mescla de relato, reflexão e narrativa - na história mundial da escravidão; Conceição Evaristo e o pretérito imperfeito estruturado na sutil ternura pelos seus personagens, mesmo os mais terríveis e violentos, no romance Ponciá Vicêncio de 2003.

\section{Lutar, esperar, envelhecer}

Antonio Candido de Mello e Souza nasceu em 1918 no Rio de Janeiro. Sua família viveu os primeiros anos da infância dele, até 1928, em Cássia - ou, como ele gabava dizer, "Santa Rita”, que Drummond recordaria nos versos ensimesmados de Brejo das almas: “(...) as melhores, mais doces namoradas/ são as de Santo Antônio do Monte e Santa Rita" - e, depois, em Poços de Caldas, ambas cidades de Minas Gerais. Seu pai era o médico Aristides Candido de Mello e Souza e sua mãe, a dona de casa Clarisse Tolentino de Mello e Souza. Mais velho além dele, Miguel e Roberto -, Antonio formou com os irmãos um trio amigo, metidos todos em um uniforme de marinheiro e no amor pelo cinema. Três meninos.

Em 1943, quando atuava como professor assistente de sociologia na USP e como crítico literário em publicações de São Paulo, casou-se com Gilda Moraes Rocha, que trocaria de nome para Gilda de Mello e Souza. Ela foi autora do clássico $O$ tupi e o alaúde, sobre Mário de 

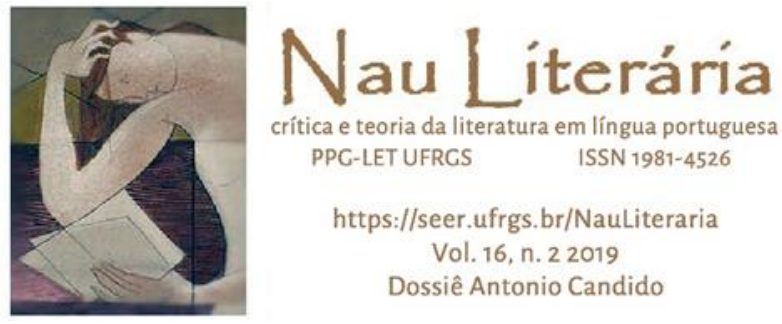

Andrade, entre diversos outros escritos. Dona Gilda, assim conhecida, era prima de Mário de Andrade, amparando-se aí certamente uma das razões para a "presença viva" dos modernistas na trajetória de Candido. Dos escritos de sua esposa, ele gostava especialmente de "Notas sobre Fred Astaire", em que Gilda argumenta que o dançarino se relacionava dinamicamente com objetos cotidianos, instrumentos musicais e o espaço ao redor (MELLO E SOUZA, 2005, p. 171-8). Gilda e Candido escreveram juntos textos sobre cinema e um prefácio para Estrela da vida inteira, de Manuel Bandeira. Tiveram três filhas, a escritora Ana Luísa Escorel e as historiadoras Laura de Mello e Souza e Marina de Mello e Souza. Três meninas.

Escorel escreveu um livro de memórias, O pai, a mãe e a filha (2010), sobre os primeiros anos de sua infância, de 1944 em diante. Conta que seus pais passavam horas e horas conversando, principalmente à noite, que algumas vezes atrasavam o aluguel, que Candido datilografava só com os dedos indicadores e que ele apreciava andar e conversar, isto é, conversar andando, com amigos - um dia, com Décio de Almeida Prado, teria feito $30 \mathrm{~km}$ a pé, conversando, conversando... Escorel também conta que o pai tinha acne no nariz e que deixou o bigode crescer a pedido dela, que teve a esperança de assim deixá-lo mais bonito, mas de nada adiantou... O casal viveu a maior parte do tempo em São Paulo, onde Candido morreu em maio de 2017. Gilda falecera em 2005.

Candido viveu quase um século, portanto. Deixou, se conto bem, uns 23 livros individuais e mais ou menos 800 artigos, ensaios, prefácios e pequenos textos, além de organizações, co-autorias e outras publicações comuns na vida acadêmica. Muita coisa ainda se vai publicar dele, cartas, estudos, diários, não sei, há material já arquivado e um tanto ainda por ser recolhido. Mas o que já está publicado é matéria suficiente para iniciarmos os trabalhos de avaliar sua trajetória e suas ideias, com o intuito de utilizá-las nestes tempos difíceis. Não que os que ele viveu tenham sido tempos fáceis: foi testemunha e ator do breve e terrível século XX e do início desse nosso século, “que confusão de coisas!".

Sobre seu amigo Arnaldo Pedroso d'Horta, num texto de 1974 censurado pela ditadura militar junto com o quarto número da revista Argumento, Candido escreveu:

Passamos juntos por muita mudança, lutamos horas sem conta em lutas sem perspectivas, esperamos sem esperança colheitas que não brotaram, ficamos homens numa ditadura e envelhecemos noutra. Ultimamente, creio que talvez discordássemos mais do que concordaríamos, se fôssemos dar um repasso nas posições de base. Mas, acima das concordâncias ou das discordâncias, diante de um homem desses haverá outra atitude além do preito? Porque são esses homens - que não querem dar exemplo, que 

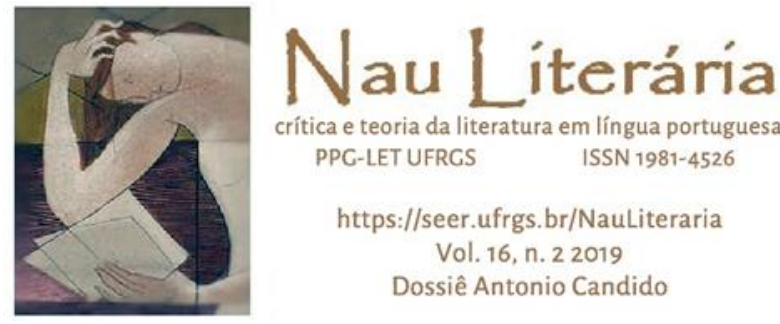

crítica e teoria da literatura em língua portuguesa

PPC-LET UFRCS ISSN 1981-4526

https://seer.ufrgs.br/NauLiteraria

Vol. 16, n. 22019

Dossiê Antonio Candido

brigam se alguém os quer louvar -, são esses os homens realmente exemplares e dignos de louvor. (CANDIDO, 2004a, p. 214)

O século vivido por Candido iniciou com a Primeira Guerra Mundial, passou pela crise de 29, entrou na Segunda Guerra Mundial - um irmão foi soldado no final desta guerra, que Candido tomou, em suas críticas literárias do período, como um sintoma de crise da civilização burguesa - avançou pela ditadura Vargas, pela guerra fria, pela ditadura civil-militar, entre colheitas que nunca brotaram e outras que talvez ainda brotem, germinem, e, enfim, o século vivido por Candido termina com o capitalismo tomando os últimos espaços ainda não mercantilizados da terra, do trabalho e do ser, quem sabe com quais consequências. 19182017... O século de Candido.

\section{Antes de nascer}

Mas, desde os pontos de vista da leitura, da escrita e da formação intelectual, não é de todo disparatado afirmar, shandianamente, que o século para Candido começou no começo do século, quer dizer, por volta de 1901, quando Aristides, seu futuro pai, então ginasiano em Campinas, comprou livros de uma coleção na qual Candido se apoiaria para dar os primeiros passos na direção do que, numa palestra para a União Brasileira de Estudantes, classificou como a leitura como forma de vida.

A mãe de Candido era de família rica e teve educação primária. A partir daí, tornou-se leitora cada vez mais escolada e atenta, pessoa reconhecida por ser extremamente culta, conhecedora dos romances franceses de seu tempo e grande admiradora de Stendhal, gosto herdado pelo filho, que, em um artigo de 1957 ajuntado no livro Tese e antítese teceu o que lhe parecia ser expresso pelo termo que usei anteriormente entre aspas, um "fichário comentado", a respeito dos gostos e experiências musicais de Stendhal. Já em "Batalhas", um ensaio tardio, de 2009, Candido comenta as cenas de guerra presentes em A cartuxa de Parma. Clarisse foi, portanto, a primeira grande educadora e mestre do jovem curioso, indicando leituras e comentando com ele os livros que ela e ele iam lendo.

A biblioteca dos Mello e Souza parece um lugar de transmissão amável do conhecimento. Um ambiente acolhedor, relativamente atualizado no que diz respeito ao mundo e seus choques, mas também relativamente autônomo e protegido. Essa imagem de um espaço- 


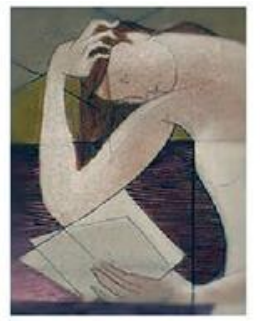

tempo prenhe de mundo e também resguardado dele por uma lógica singular, que era menos alienação do que resistência, menos afastamento do que distanciamento, se tornaria, para o crítico maduro, a imagem das melhores obras literárias.

Num artigo de 1989, "O recado dos livros”, Candido conta a história da formação dessa biblioteca, mais ou menos assim: os primeiros livros adquiridos pelo ginasiano Aristides iam pelo culto à ciência (Max Nordau, Luis Büchner, Herbert Spencer, em tradução portuguesa), pela história (a obra completa de Oliveira Martins, muito utilizada por Candido depois), por Eça de Queirós (“assinalado com lápis anticlerical”, mas anos depois deixado para lá em prol de Dostoievski; Candido, ao contrário do pai, foi permanente leitor admirado do escritor português), por Olavo Bilac, Alberto de Oliveira e pel'Os sertões. Este último teria apresentado a Aristides um modo de abordar os "problemas do país" (CANDIDO, 2004a, p. 237-8). Alberto de Oliveira reapareceria de quando em vez na trajetória do crítico, especialmente em $\mathrm{Na}$ sala de aula, numa inventiva leitura do hermetismo do poema "Fantástica": "Erguido em negro mármor luzidio/ Portas fechadas, num mistério enorme,/ Numa terra de reis, mudo e sombrio,/ Sono de lendas um palácio dorme". Para Candido, o poema de Oliveira produziria - é preciso prestar atenção nesse verbo: produzir - "um objeto plasticamente belo, autônomo, existindo num espaço regido por leis sem medida comum com as que regem o mundo dos homens" (1985, p. 67).

Os sertões ganharia na pena de Candido status de interpretação do Brasil e passaria a ser lembrado também ao lado daquelas interpretações que procuram compreender outros países da América Latina, como Facundo. "Euclides da Cunha é quase um iluminado", escreveu em 1952, num texto que remete a operações gabadas em vários outros intelectuais: a síntese e a visão de conjunto. “As simplificações que operou, nas sínteses das grandes visões de conjunto, permitem-lhe captar a realidade mais profunda do homem brasileiro do sertão" (REMATE DE MALES, 1999, p. 33). Cinquenta anos depois, o livro que ensinara a seu pai uma vereda para os problemas do país, impressionaria o sociólogo Antonio Candido, tanto pelo que Euclides conseguira quanto pelo que não conseguira ver. Estava bem definida a compreensão de que aos limites de cada pensador não se deve mocar sem mais aquela, nem fazer pouco. Às vezes, são eles mesmos a estrutura básica dos ganhos de visão e de crítica alcançados por quem vem depois. A reflexão dialética sobre a literatura nunca parte apenas dos tranquilos acertos do passado, mas também dos angustiados equívocos de quem veio antes. 

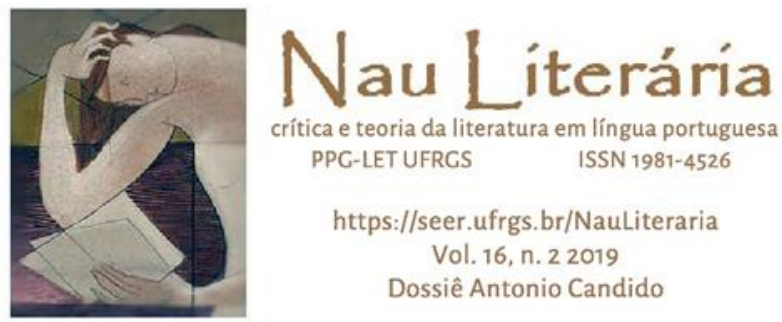

Quando o jovem Aristides foi estudar medicina, se não me equivoco nos cálculos, mais ou menos entre 1905 e $1910^{2}$, no Rio de Janeiro, comprou e leu Darwin, Haeckel, Spencer, Comte, todos ou quase todos em francês ou tradução francesa. Para Candido, seu pai tinha consolidado nesse período um materialismo ateu. Em literatura, Aristides leu seu tanto de Anatole France, que, ao lado de Eça, foi um dos preferidos na época, além de Machado de Assis e Alphonse Daudet. Todos esses seriam lidos por Candido quando ele tinha entre 13, 14 e 18 anos. Eça, principalmente, France e algum Machado dispararam o que Candido entendeu ser a “aquisição de dúvidas", seguida da "aquisição de certezas", sobre a qual falarei adiante.

Para a história que estou contando tem grande importância o fato de a biblioteca ter incorporado nesse período uns quantos intelectuais brasileiros: Sílvio Romero, José Veríssimo, Oliveira Lima, Manoel Bonfim, este último anotado por Aristides com especial interesse. Todos foram fundamentais para a educação de Antonio Candido, mas os exemplares dos livros de Sílvio Romero seriam uma das bases sobre as quais ele construiria a tese de livre-docência em 1945 que abriria caminho para o seu futuro como professor de literatura. Romero, Veríssimo, Lima e Bonfim foram folheados, lidos e relidos constantemente tanto ao longo da juventude de Candido, quanto depois, conforme os anos iam passando. Seu pai lia em voz alta trechos de Oliveira Lima. Romero se tornou consulta cotidiana, inclusive para resolver provas escolares. Na hora de escolher o tema da tese para o concurso de 1945, o jovem - então com 25 anos professor assistente de sociologia recebeu por carta uns dez bons conselhos de temas sugeridos por Mário de Andrade, um mais interessante que o outro, aos quais voltarei mais tarde. Optou, todavia, por escrever sobre Sílvio Romero.

Entre o final de 1911 e o final de 1912, Aristides fez uma estadia de atualização profissional na França e na Suíça. Nessa época, ele começou a ler traduções francesas de Goethe e Schiller, romances franceses recém publicados, e livros sobre música e estética. Anos depois, Candido tomou um gosto - amparado num dos volumes adquiridos pelo pai durante essa época - que perduraria até sua morte: a leitura das Flores do mal, de Baudelaire. "No meu tempo de moço, quatro poetas franceses formavam uma espécie de constelação privilegiada, que servia

\footnotetext{
${ }^{2}$ No discurso de recebimento do título de doutor honoris causa pela Universidad de la República, de Montevideo, Candido assinalou: "Em setembro de 1909 meu pai (...) já no fím do curso médico, teve uma oportunidade que marcou a sua vida relativamente curta, ao fazer parte de uma missão enviada a Montevidéu pelo Ministério das Relações Exteriores, composta por estudantes das três principais escolas superiores do Rio de Janeiro" (2018, p. 227).
} 


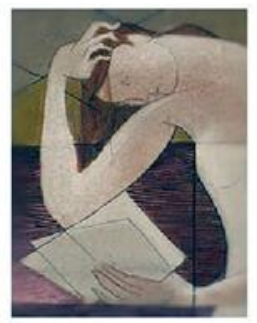

de referência para conceber a poesia: Baudelaire, Mallarmé, Verlaine e Rimbaud" (2004a, p. 130). Vale assinalar a expressão "referência para conceber a poesia" relacionada aos quatro franceses, já que virou lugar comum ligar Candido aos propósitos poéticos modernistas. (Fico me perguntando até que ponto a "referência" serviu como base para o acolhimento das ideias modernistas, lidas bem depois, como se verá, e até que ponto ela se realiza como um núcleo formativo quase inconsciente para os critérios de avaliação até mesmo em Formação da literatura brasileira, mas isso é assunto para outros ensaios). A partir do Goethe comprado pelo pai oito ou nove anos antes do nascimento de Candido, conformou-se uma moléstia grave denominada por Candido como "mania bibliográfica": comprava traduções do Fausto em várias línguas e depois as lia e comparava. As manias bibliográficas já tinham se manifestado e se tornariam crônicas e incuráveis.

Por volta de 1915 e 1916, o pai de Candido - que, contudo, ainda não nasceu - fez um curso com o famoso sanitarista Oswaldo Cruz, o que talvez tenha dado algumas cores da nova camada de sedimentação da biblioteca. Ibsen, Dostoievski, Nietzsche e Bergson se assentaram nas prateleiras, todos, dali por diante, interesses centrais da vida do médico. Candido escreveu sobre isso: "Certo dia [meu pai] me disse que, depois de ter conhecido a [...] obra [de Dostoievski], nunca mais conseguiria ler duas linhas de Anatole France ou Eça de Queirós, autores sem profundidade" (2010, p. 143). Pouco antes de morrer, aos 56 anos, Aristides estava lendo uma biografia de Henri Troyat sobre o escritor russo.

Como na época do curso com Oswaldo Cruz a primeira grande guerra estivesse acontecendo, foi também a época em que apareceram nas estantes livros a respeito dela. Em seguida, veio a revolução russa e as biografias de Lenin e de Trostki. De Romain Rolland, que ganhara o prêmio Nobel em 1915, o médico resolveu ter tudo, talvez entusiasmado pelas leituras feitas por Clarisse, já que Candido reforça que "no meu tempo de menino", os romancistas prediletos dela eram Paul Bourget e Romain Rolland, depois, como dito, Stendhal.

Por volta do período em que o menino Antonio nasceu, títulos brasileiros se alargaram nas prateleiras, agora tomadas por Antonio Torres, Monteiro Lobato, Gilberto Amado, Gastão Cruls e Oliveira Viana; deste, Aristides gostava do Populações meridionais do Brasil. Antonio Torres e Gastão Cruls eram muito camaradas um do outro. Em 1950, Cruls organizaria um livro, Antonio Torres e seus amigos, que, provavelmente, ficou na memória de Candido quando se tratou de dar título em 1980 à biografia de Teresina - Teresina e seus amigos. 


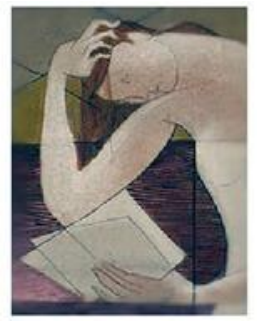

De Sílvio Romero, passando por Euclides da Cunha, Oliveira Lima, Manoel Bonfim e chegando a Oliveira Viana estava montada, na biblioteca de Aristides, uma estrutura de questões, sobretudo mediadas pelas noções de raça e de cultura, que iam dando formas - em meio a equívocos terríveis - a outras questões que seriam, reformuladas e reenquadradas, as do Candido adulto. Ao mesmo tempo, de Eça, passando por Machado, Stendhal e Goethe, sem esquecer Baudelaire, estavam postas referências poéticas e literárias que definiram o substrato das ideias de "coerência", "estrutura" e "composição", fundamentais para o crítico literário, a partir do início dos anos 1940.

Como Candido gostava de lembrar, na fase de infância da leitura, fase de "aquisição de certezas", livros ruins podem ter grande valor. Às vezes, quanto piores, melhor. "Creio que o Tesouro da Juventude me marcou para sempre, porque a partir dele sempre fui dispersivo e curioso de aprender pela superfície, sem me aprofundar muito. Ou, pelo contrário, ele me encantou e ajudou porque o meu temperamento era este" (CANDIDO, 1984).

Em menino, nem se diga, Candido não lia o que estava disponível na biblioteca do pai. Por volta de 1924, 1925, ainda em Santa Rita, ouviu mesmo falar de filmes e de heróis de cinema. A mãe detestava Chaplin, o pai adorava. Nas férias no Rio, os irmãos assistiam essas "fitas", que chegavam aos cinemas do interior de Minas atrasadas e sem variedade.

Nos relatos de Candido, as primeiras leituras datam de 1926. Aos domingos ele e os irmãos iam a matinês e por isso ele começou a ler sobre cinema: colecionou a revista Cinearte até 1928. Foi em 1926 que Beau Geste - filme com Ronald Colman, Neil Hamilton e Ralph Forbes - impressionou Antonio, Miguel e Roberto. Era uma história sobre irmãos que iam para a Legião Estrangeira. Roberto, o caçula da família, serviria na Segunda Guerra, em 1944 e 1945. Beau Geste o marcou tanto que, em 1995, ele publicaria o extraordinário romance autobiográfico, Mina $R$, testemunhando episódios da guerra. O filme serviu como fio condutor para o enredo. Um trecho do livro escrito por Roberto é assim:

\footnotetext{
E lá pelas tantas ficamos com fome, tiramos a ração $\mathrm{K}$ da patrona e fomos comendo, comendo e conversando, o chão do caminho forrado de cadáveres em mau estado que eles iam levando para enterrar, tudo gelatinoso chacoalhando batendo nas pernas da gente. Não estavam duros esticados como eu achava que devia ser. E quantos cadáveres vimos. E fizemos. E eu que antes quando via um dedo cortado já começava a ter vertigem. Como é que pode, não? (MELLO E SOUZA, 1995, p. 39)
}

Nele se percebe a tentativa de mostrar a diferença entre o que o cinema levou o jovem a achar que a guerra fosse e o que a guerra foi quando sofrida. "Como é que pode, não?". 


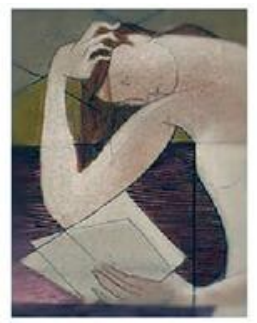

Além dos filmes em Cássia, os irmãos promoviam durante as férias no Rio "orgias de cinema". Isso foi por volta de 1926, 27 e 28. Candido, cinquenta anos depois, recordaria vivamente - teria tudo anotado? - filmes como Sangue e areia, O Águia, O filho do Sheik, Os três mosqueteiros, O pirata negro, Dom Q, o filho do Zorro, Amor de boêmio, A fera do mar, Tesouro de prata. "Nessa altura, eu já estava sabido em cinema, e lia não apenas Cinearte, Seleta, Cena Muda, mas a recente e portentosa Cinelandia, editada em espanhol por alguma grande companhia internacional, com papel glacê e ilustrações incríveis” (Recortes, p. 245).

Em meio a tantos filmes, Amor de boêmio acaba sendo um primeiro impulso para a leitura de François Villon, conforme registrado num ensaio de 1997, "Crítica e memória", reunido em $O$ albatroz e o chinês. Mas não foram as qualidades da fita que se fixaram na memória de Candido. Era, disse ele, um filme inglês "muito ruim". Ficou fascinado sim por Gengis Khan e pelo império das estepes, a respeito dos quais provavelmente se informava por meio de dicionários e enciclopédias, que tanto o fascinavam.

O menino quer ver o verbete Narciso, e dali salta para Napoleão, depois Nelson, depois Neoptolemo, depois Nevada, depois Napier, depois Nigra, e assim vai sem querer acumulando a informação sem a qual não há cultura. Com enciclopédia na mão o mundo se desdobra aos nossos olhos e o tempo voa imperceptivelmente. (CANDIDO, 1984, mimeo)

Desta forma se manifestou no pobre Candido pela primeira vez uma "mania bibliográfica". Vale a pena citar com extensão:

Ali por 1927 assisti a uma fita que me fascinou, Amor de boêmio, na qual John Barrymore fazia o papel do dito poeta (que eu ignorava ter existido), numa Paris cheia de neve e de aventuras sensacionais, com armaduras, lanças, catapultas, torres, e Conrad Veidt no papel de Luís XI. Entusiasmado, recolhi na imaginação aquela revoada de peripécias centralizadas pelo esperto e generoso mocinho, como dali a pouco me entusiasmei por outro, chamado D'Artagnan./ Talvez eu já soubesse que se tratava de personagem real quando vi a segunda fita sobre ele, $O$ rei vagabundo, colorida e cantada, com o barítono Denis King dando um ar de opereta a aventuras medievais manipuladas à Hollywood. Isso seria cerca de 1931, mas só cheguei mais perto de Villon como poeta três ou quatro anos depois, graças ao acaso de uma leitura que me impressionou: a das ideias de Rodin expostas a Paul Gsell em entrevistas que este reuniu no livro L'Art./ Num dos capítulos o escultor explica, superando a distinção entre bonito e feio, que "na arte, é belo apenas o que tem caráter". O entrevistador ilustra o conceito reproduzindo e comentando uma das suas obras, a estatueta La Belle Heaulmière, ilustrada por um trecho do Testament de Villon... (CANDIDO, 2010, p. 34) 

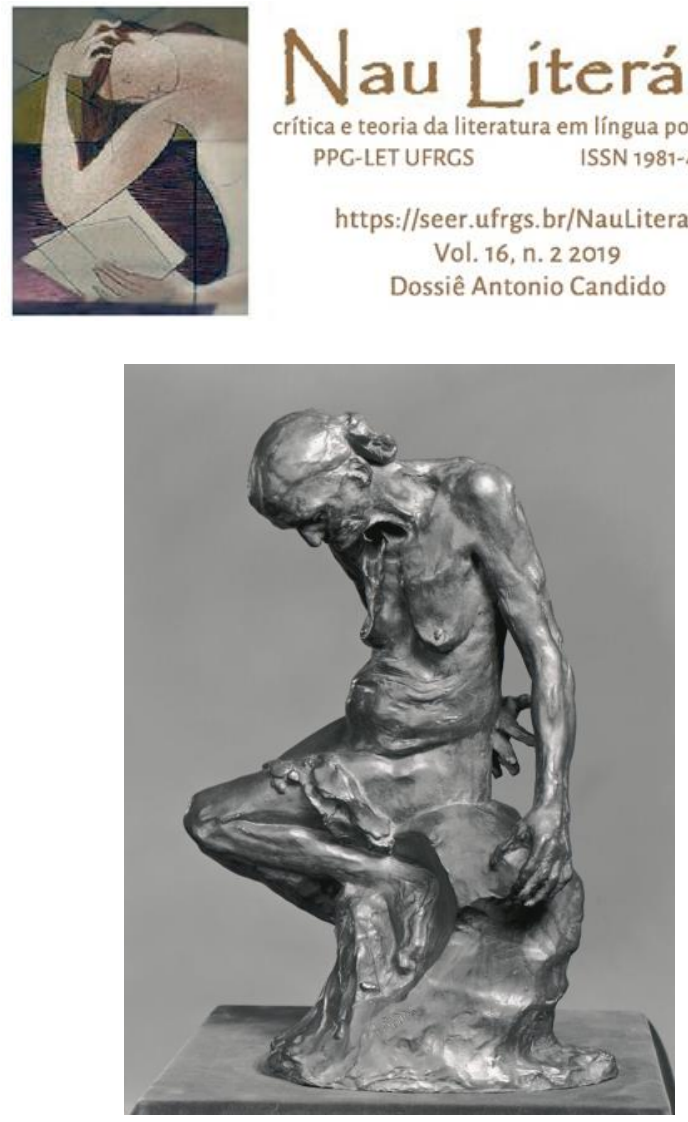

Figura 1 - La Belle Heaulmière

Em 1928, os irmãos cinéfilos inventaram uma caixa de sapato que serviu como enquadramento para reproduzir filmes montados com figuras recortadas das revistas que Candido tanto lia. Em 1929, acompanharam o pai e a mãe em estada em Paris, onde viram o cartaz de um filme com Gary Cooper, que Candido conhecia da Cinelandia. Foi um dos primeiros filmes com som sincronizado. Um avião crivado por balaços despencava do céu. Tá tá tá tá. Com esse filme, Candido marca o final da era do cinema mudo, o final de sua infância, o início da adolescência e o início de uma era de catástrofes (CANDIDO, 2004a, p. 241-6). Tá tá tá tá.

\section{Teresina contra o fascismo}

Aristides voltou à Europa, Berlim e Paris, para atualizar seus conhecimentos médicos. Toda a família foi junto. Isso ocorreu entre 1928 e 1929. Nesse tempo, cresceu um tanto a estante de literatura francesa: Proust, Valéry, Paul Morand, Francis Carco, Jean Cocteau, Jules Romains. A partir de então, o médico sempre buscaria obras sobre Dostoievski ou sobre Nietzsche. De acordo com Candido, dos livros que neste período se acomodaram na biblioteca, parecem ter ficado para si os de Proust, que se tornaria outra de suas "manias bibliográficas", e Nietzsche, de quem avaliou a obra como um todo no ensaio "O portador", reunido em $O$ observador literário, de 1959. Entre outras coisas, "O portador" procura resguardar Nietzsche 


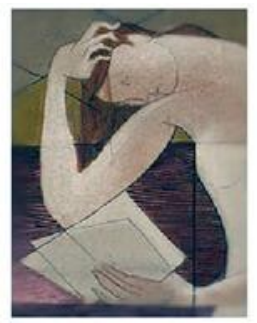

das apropriações fascistas e nazistas ou mesmo das liberais, evidenciando a importância de ler o filósofo numa época - o pós-guerras - em que o "homem na sua pura humanidade" precisava "reorganizar o mundo sem apelo ao divino" (CANDIDO, 2008, p. 87).

Durante 1929, Clarisse leva os meninos para passear com roupa de marinheiro pelas ruas de Berlim. Há no ar medonha bravata militarista, muito criticada por ela. Transeuntes elogiam os meninos e dizem que vão dar belíssimos soldados. Nesses passeios, certo dia, passam por um muro onde se lê: Judas den Tod, morte a Judas. O Candido menino não entende o significado da frase, que permaneceria por anos em sua mente.

Incêndios aconteciam repentinamente na cidade. Moradores falavam que tudo era provocado pelos judeus. Clarisse ficava encafifada: “Os judeus? Mas por quê?”. Soube-se depois que os incêndios eram ocasionados pelos nazistas. As primeiras notícias da crise de 1929 começavam a aparecer (CANDIDO, 2004a, p. 246-51).

Nesse momento, a biblioteca de Aristides ia aumentando e a família já estava em Poços de Caldas. As lembranças de Candido mostram uma primeira expansão da convivência social. Enquanto até aqui aparecem os pais e os irmãos e um ou outro amiguinho, agora começam a aparecer jardineiros, sapateiros e a grande Teresina, figura que, pela força de suas "convinções", encanta os leitores do livro intitulado com seu nome.

Ela viveu - repito - em Poços de Caldas entre 1931 e 1951. Anarquista e socialista ou vice-versa, leitora voraz, muito estudiosa, foi grande amiga da mãe de Candido, depois de ter militado em São Paulo. Candido conheceu Teresina quando era menino - chegou a ter aulas com ela - e a auxiliou, mais tarde, a resolver pepinos com hóspedes, entre outras coisas. Candido a conheceu bem. Admirava a vida simples e reta vivida por Teresina. Ao perceber que os cães e gatos dela tinham pulgas, ele comunicou a dona, que ficou indignada com a insinuação. Candido lembrava vividamente o quanto Teresina pedia para que ele prestasse atenção nos olhos das pessoas, observação que era o ponto de partida dela para longas reflexões sobre a personalidade por trás de cada olhar.

Quando Mussolini foi morto e pendurado de cabeça para baixo em Turim, em 1945, Teresina ficou sabendo e tomou um porre de vinho ruim, devidamente compartilhado com o gato. A passagem é contada por Candido num trecho de antológica simplicidade estética, efetividade narrativa e profundidade carinhosa. 

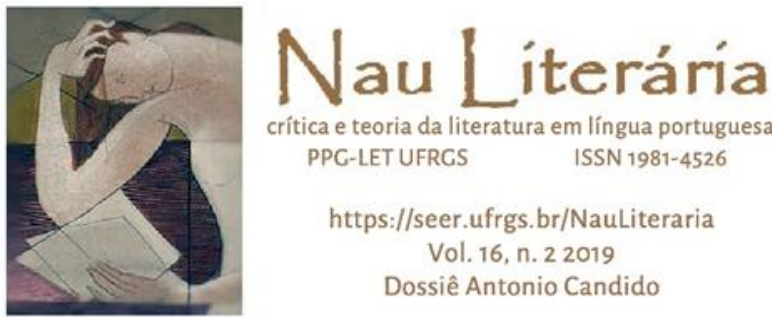

crítica e teoria da literatura em língua portuguesa

PPG-LET UFRCS ISSN 1981-4526

https://seer.ufrgs.br/NauLiteraria

Vol. 16, n. 22019

Dossiê Antonio Candido

Numa cidade cheia de filhos de italiano e de italianos, geralmente acomodados com o regime da mãe-pátria, foi longa, pertinaz, inflexível e apaixonadamente antifascista, deblaterando contra o Fascio local (...), contra a simpatia mussolinizante da burguesia e das autoridades, que gostavam de gabar as vantagens de "um governo forte". Falou, pregou, escreveu, se expôs durante vinte e poucos anos, até o dia em que o regime odiado caiu na sua terra e, afinal, ela viu as fotografias horríveis do Duce pendurado de cabeça para baixo. Delirante, tomou para comemorar uma quantidade irracional de mau vinho que fez questão de dar também ao gato. Mas estava velha, nunca mais lavou inteiramente a amargura antifascista e a pungência do horror à guerra, -- apesar de ter saboreado a mudança (...). (CANDIDO, 2007a, p. 47)

A Teresina socialista, muito avessa a contorcionismos verbais para justificar covardias e autoenganos, se faz presente ao longo de diversos momentos da trajetória de Candido, ganhando provavelmente mais peso quando vamos lendo a obra dele em sua extensão. "As coisas essenciais são simples, enquanto os conceitos retorcidos e ambíguos, e as cascatas de palavras, podem servir para esconder o vazio ou evitar o confronto com a reta singeleza dos princípios que definem o necessário para viver com dignidade", assinalaria o intelectual prestes a se aposentar, em 1975, ao relembrar o congresso brasileiro de escritores de 1944 e, nele, a produção de um documento lacônico lançado contra Vargas (2007a, p. 103). Simples e essencial terá sido Teresina que, quando um amigo aderiu ao fascismo, respondeu com uma carta de uma linha dizendo tudo: "Sei un canne".

Poços de Caldas era uma cidade talvez mais multifacetada do que Santa Rita. Além de ela ser maior, o menino também ficava maior. Pouco a pouco se apresentava como leitor e os livros desbancavam o cinema como meio de viver e de se relacionar com os demais.

Lembro de ter conhecido na minha infância, em Poços de Caldas, o velho sapateiro italiano Crispino Caponi que sabia o INFERNO completo e recitava qualquer canto que se pedisse, sem parar de bater as suas solas. (...) Se me for permitida outra lembrança pessoal, contarei que quando eu tinha doze anos, na mesma cidade de Poços de Caldas, um jardineiro português e sua esposa brasileira, ambos analfabetos, me pediram para lhes ler o Amor de perdição, de Camilo Castelo Branco, que já tinham ouvido de uma professora na fazenda onde trabalhavam antes e que os havia fascinado. Eu atendi e verifiquei como assimilavam bem, com emoção inteligente (CANDIDO, 2004b, p. 190).

Estas duas lembranças aparecem na conhecida palestra transformada em ensaio, "O direito à literatura”. Também aparecem em outros momentos. Em 5 de agosto de 2006, na festa de inauguração da biblioteca da Escola Nacional Florestan Fernandes, Candido se lembrou outra vez do "velho e rabugento Crispino". O segundo Caderno de Estudos da Escola Nacional Florestan Fernandes traz, além do texto apresentado por Candido na ocasião, a reprodução de uma fala em que é possível perceber o quanto a prosa dele esteve muitas vezes próxima da 


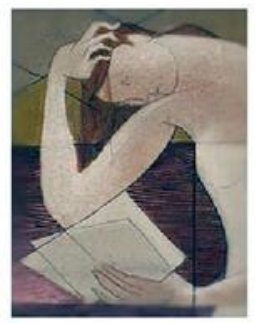

levada da prosa de setores populares engajados em diferentes lutas. Referi-me no início deste ensaio ao texto sobre Arnaldo Pedroso d'Horta, com suas metáforas em torno do plantio e da colheita. Veja-se o seguinte trecho de Adelar João Pizetta, membro do MST, autor da apresentação do Cadernos de Estudos da ENFF:

\begin{abstract}
Essa publicação significou a realização de mais um dos objetivos do MST: o de colocar à disposição da Escola e dos seus leitores uma ferramenta que nos auxilie no trabalho de preparo da terra e no trabalho do plantio, para o qual esperamos uma bela colheita. É certo que ainda não chegamos ao tempo da colheita, mas estamos em plena época do plantio (...). (CADERNOS DE ESTUDOS DA ENFF, 2007, p. 9)
\end{abstract}

No texto de Candido sobre Arnaldo o tom é mais incerto e ponderado, mas está carregado das mesmas imagens esperançosas e populares utilizadas pelos seus amigos e companheiros do MST. Nada de conceitos retorcidos e ambíguos. Basta a palavra aberta, trazida com carinho e apreço pelos valores que ajudam a vida a se realizar: solidariedade, esperança, cuidado (nem sempre, anoto de passagem, esse tom prevaleceu quando Candido trazia à discussão os povos originários, aos quais se referia como selvagens e primitivos. Essa contradição daria muito o que pensar, mas precisa ficar para outro momento).

O tom, aliás incerto, não era por nada. O século pesou. De 1930 a 1942 - quando morreu - o pai de Candido procurou ler obras sobre nazismo e fascismo, a Rússia soviética, a guerra, os problemas brasileiros - Casa-grande e senzala e a coleção Brasiliana, organizada por aquele que viria a ser na USP supervisor do sociólogo Antonio Candido, Fernando Azevedo. Aristides, nesses últimos anos de sua vida, passou a ler Keyserling e existencialistas cristãos russos, Berdiaev e Chestov, conhecidos por escreverem sobre Dostoievski (CANDIDO, 2004a, "O recado dos livros").

De 1933 a 1942 as interpretações do Brasil já disponíveis, de Sílvio Romero a Sérgio Buarque de Holanda - que se tornaria grande amigo de Candido -, teriam sido fundamentais para quem adotava posição de esquerda. Em conjunto, Candido as considerou, pelo menos a partir de certo momento, de acordo com a seguinte perspectiva de empenho antioligárquico: "Traziam a denúncia do preconceito de raça, a valorização do elemento de cor, a crítica dos fundamentos 'patriarcais' e agrários, o discernimento dos fatores econômicos, a desmistificação da retórica liberal" (2007a, p. 127). 


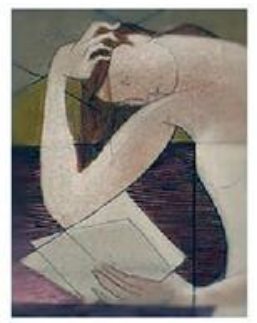

Mas estou acelerando o tempo. Voltemos ao início dos anos 1930. Era hora de outras referências, além daquelas oriundas dos gostos do pai, da mãe e dos planos da indústria cinematográfica.

Ali por 1931-32 uns primos meus, estudantes de Medicina em Belo Horizonte, achavam graça nas minhas leituras, bolorentas e fora de moda segundo eles. Eu andava mergulhado em Alexandre Herculano, em Victor Hugo, na tradução do Fausto, por Castilho, e quando vinham de férias eles me davam trela, divertidos com o meu ingênuo pedantismo de bichinho dos livros, mostrando os que achavam dignos de apreço e tinham conhecido por obra de um companheiro de pensão, o estudante Guilhermino Cesar. Foi assim que vi pela primeira vez as capas multicores de Pauliceia desvairada, Laranja da China, além de outras mais tranquilas, como a de Brás, Bexiga e Barra Funda. (CANDIDO, 2010, p. 101)

\section{Eça e Martins Fontes, um anarquista}

Seu gosto, afirmava o próprio Candido, era até então limitado pelo dos pais, formado antes, e pela biblioteca disponível na pequena cidade de Minas; cidade que, além disso, contava com uma excelente livraria, montada para prazer dos turistas cultos, beletristas ou aspirantes muito presentes na vida da cidade. Candido teria nos anos seguintes conta aberta pelo pai tanto na livraria de Poços de Caldas quanto em outras de São Paulo, o que aconteceu também na formação de José Guilherme Merquior e pode ser um traço da trajetória de alguns intelectuais brasileiros. Agora, porém, o gosto do adolescente Antonio começava a mudar. Por volta de 1933, 1934, iniciou, sem abandonar de todo as tendências anteriormente cultivadas, a leitura de literatura brasileira contemporânea. Sobre as tendências anteriores, escreveria:

Eça era o mais lido e conhecido, sendo difícil para um jovem de agora avaliar o que foi a sua fama por aqui (...). De fato, muitos sabiam de cor trechos dos livros de Eça e os seus personagens eram comentados como gente viva. No ginásio e na universidade fazíamos testes divertidos de conhecimento, como: quem e em que romance é visto com seus bigodes louros no fundo de uma frisa? Qual o personagem cujo alfinete de gravata é um macaco comendo banana? (CANDIDO, 2010, p. 102)

Os pais de Candido a essa altura não davam muita bola para Eça, leitura disseminada entre várias classes de leitores, "incultos, semicultos e cultos" (CANDIDO, 2010, p. 139). A prova de que os pais pouco apreciavam Eça, afirmaria Candido, é que tinham "apenas" O crime do Padre Amaro, O primo Basílio, O mandarim, A correspondência de Fradique Mendes, Cartas de Inglaterra. Candido e seus irmãos, todavia, adoravam o escritor português e faziam torneiros de memória para ver quem mais sabia de cor trechos e pormenores (idem, p. 143). 


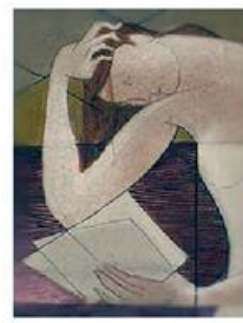

Essas leituras de Eça seriam de uma geração inteira de jovens e talvez tenham retardado, pondera Candido, talvez tenham de certo modo preparado, acrescento lateralmente, um público para os romances do Nordeste, a partir de $O$ quinze (1930), de Raquel de Queirós.

Em 1934 acontece algo que puxa o fio das recordações de Candido, anos depois, condensando afetos diversos. Martins Fontes, um anarquista, dá um presente para Clarisse:

\begin{abstract}
Num ato de aliciamento, deu para minha mãe ler $O$ anarquismo, de Kropotkin, em cuja folha de guarda ele havia escrito uma quadra louvando o grande revolucionário. Era a recente edição da Unitas, de capa preta e amarela; lembro que minha mãe leu e comentou com simpatia./ Essa simpatia tinha alguma coisa a ver com o seu temperamento avesso à obediência; talvez ela encontrasse, neste e outros textos, certa esperança utópica de insubmissão institucionalizada. Basta dizer que uma de suas citações prediletas era a frase de Diderot que os anarquistas subscreviam: "La nature n'a fait ni maitre, ni serviteur; je ne veux ni donner, ni recevoir des ordres". / Mas havia outro motivo para esta boa vontade em relação à doutrina que no consenso da maioria era a própria expressão da bagunça: a amizade afetuosa e a convivência quase diária de sua queridíssima dona Teresina Carini Rocchi, socialista ardorosa muito simpática ao anarquismo, que, segundo ela, era em princípio a posição mais coerente e avançada. Morava perto de nós, e na sua casa meus pais conheceram Edgard Leurenroth, que os encantou pela delicadeza, dignidade e firmeza de convicções. (CANDIDO, 2004, p. 203-4)
\end{abstract}

O socialismo de Antonio Candido precisa ser pensado desde o prisma da "presença viva" do anarquismo em sua trajetória.

\title{
6 São Paulo
}

Por volta de 1937, 38, Candido estava em São Paulo. Tinha ido para estudar medicina, mas não passou no vestibular. Ia aproveitando a vida cultural da cidade. Lia, via filmes, ia ao teatro, estudava no pré-jurídico. Seu pai mais uma vez - de acordo com as palavras do próprio Candido - não regateava com livros, o que lhe permitiu ir formando, pouco a pouco, uma biblioteca própria.

Nesse período de encantamento com São Paulo e início de estudos para entrar no curso de Direito, encontrou na "imensa" Livraria Universal, uma edição das poesias de Villon, lançada em 1936, e que o acompanharia por muito tempo: “(...) a poesia de Villon se tornou companheira, no terreno preparado vagamente pelos filmes da infância” (CANDIDO, 2010, p. 36). Notam-se os traços de um processo de formação: dados imprecisos mal apanhados durante a infância eram reformulados na constituição de uma insistência de estudo e pesquisa. $\mathrm{O}$ 


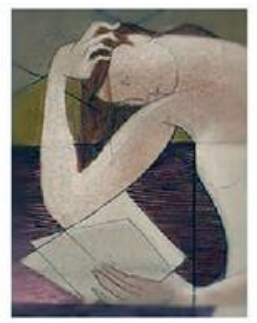

exemplar da coleção Magna, vislumbrado na Livraria Universal, dava feição concreta a um anseio ou curiosidade de leitura que vinha desde 1927.

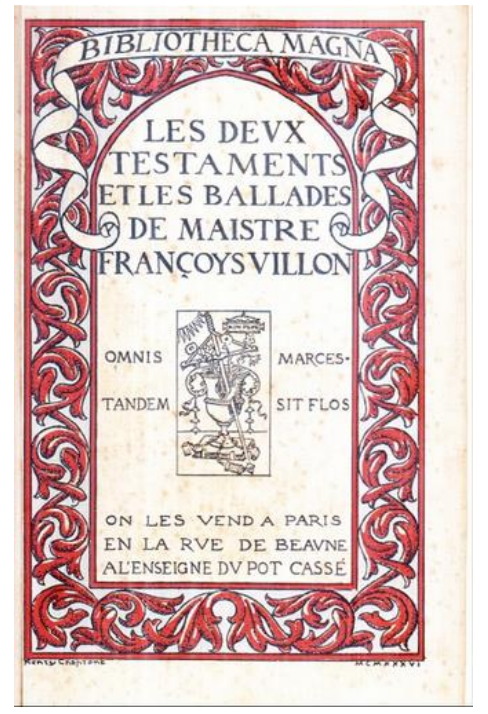

Figura 2 - Capa da edição de Testaments et les Ballades que Candido encontrou em 1936

Apenas sugeri que a razão porque Candido estava em São Paulo naquele período era a entrada no curso pré-jurídico (CANDIDO, 2004a, p. 252). De fato, ele cursou Direito, mas em 1943 decidiu não se bacharelar, já que desde 1939 cursava também a faculdade de Sociologia, que acabou absorvendo seus interesses e planos. Ainda por cima, em 1942 iniciou as tarefas como professor assistente de sociologia na USP. O curso de Direito, em parte um projeto de seu pai, ficou para lá (idem, p. 255).

Entre os professores de graduação em sociologia, Jean Maugüe foi o mais admirado por Candido e por diversos de seus amigos. Era stalinista convicto, apaixonado por música, literatura e pintura. Dava aulas de filosofia. Exortava: "Quero que a filosofia lhes sirva para ler melhor o jornal, analisar melhor a política, compreender melhor o seu semelhante, entender melhor a literatura e o cinema". O primeiro curso de Maugüe frequentado por Candido, que tirou nota mediana, era sobre emoções, tendo Freud por base. É sobre Freud um dos únicos textos disponíveis de Maugüe para o público brasileiro. Um ensaio, publicado por ocasião da morte em 1939 do autor de Mal-estar na civilização, "Os anos de formação de Sigmund Freud" (ao qual o título do presente ensaio presta homenagem). Creio ser até hoje uma excelente introdução ao pensamento de Freud e uma chance de rever o fio da trajetória de Maugüe no Brasil, o professor que menos escreveu e mais influenciou as primeiras gerações da USP, que, 


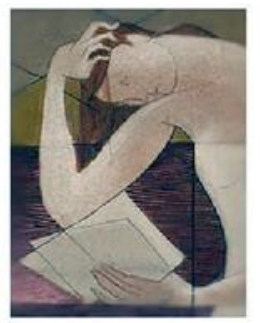

vale lembrar, tinham aulas com Fernand Braudel, Claude Lévi-Strauss, entre outros. Candido ainda cursou outras disciplinas ofertadas por Maugüe, sobre Schopenhauer, Nietzsche e Hegel, tudo na perspectiva de uma "larga dose de marxismo muito aberto" (CANDIDO, 2010, p. 185 e ss.). Maugüe iniciava as aulas falando de fatos do dia, filmes, livros etc., depois entrava no conteúdo. Candido e Azis Mathias Simão, dileto amigo, engajado ao longo do tempo em várias associações e partidos de esquerda, um dos militantes a quem Teresina e seus amigos está dedicado, conheceram-se nas aulas do grande professor. Nos jornais da época, Maugüe aparece em fotografias durante palestras. Tem um sorriso interrogador, composto não apenas pela boca, mas pelos olhos, sobrancelhas e testa. A julgar pelo olhar expresso nas fotografias, tenho cá para comigo que Teresina teria gostado de Jean Maugüe.
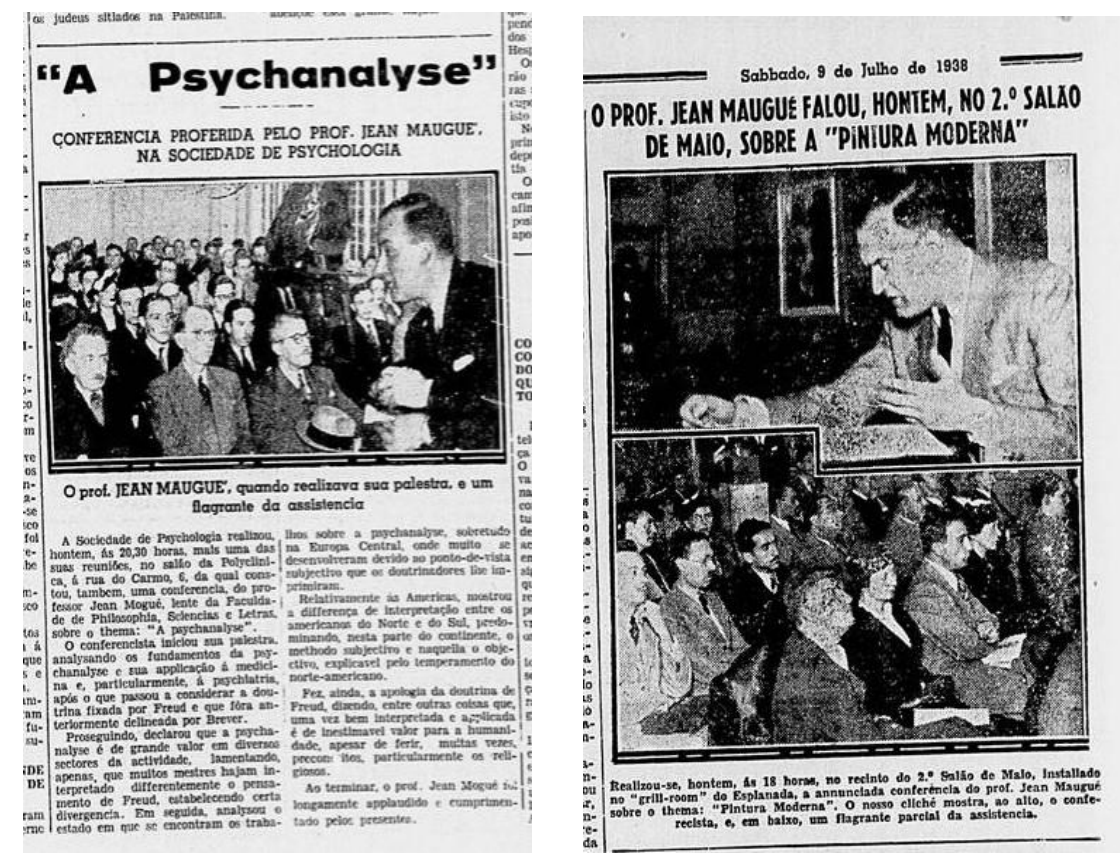

Figuras 3 e 4: Duas notícias sobre Maugüe publicadas no Correio Paulistano em 1938 e 1939

Depois das aulas de Maugüe, que começavam às 17h, uma patota se juntava nos fundos da Confeitaria Vienense, para tomar chá e conversar, às vezes tomar sorvete. Os encontros na confeitaria deram origem aos planos da revista Clima, na qual Candido escreveria pelas primeiras vezes no que podemos denominar esfera pública. Na Vienense em 1939 Decio de Almeida Prado apresentou para a turma Paulo Emílio Salles Gomes - outro dos amigos militantes a quem Teresina está dedicado. A patota era, em geral, "apolítica”, mas logo sentiuse como que convocada pela militância de Paulo Emílio, que chegou a repreendê-la. Mesmo 


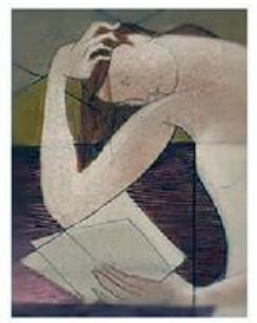

reprendida, acolheu bem ao novo amigo, tanto que ele participaria ativamente da revista Clima entre 1941-44.

\title{
7 Poesia e política
}

Os tempos eram então de novas leituras, socialização mais ampla e início de militância. Eram também de projetos de publicação.

A maneira como leituras e militância começavam a se dialetizar talvez tenha encontrado ressonância quando um exemplar de Sentimento do mundo, o segundo livro de Carlos Drummmond de Andrade, de 1940, caiu nas mãos de Candido.

\begin{abstract}
Eu era aluno de segundo ano na Faculdade de Filosofia da Universidade de São Paulo, onde apareceu certo dia um colega arvorando a preciosidade. O exemplar pertencia a Rubem Braga, com dedicatória e tudo, mas andava rodando de mão em mão e, por confiança, do colega, parou nas minhas uns dois ou três dias. A impressão dominante foi de coisa nova, inclusive naquele terreno difícil onde os moços do meu tempo procuravam uma solução que convencesse para além da geralmente fraca poesia participante. Era como se o poeta tivesse afinal conciliado de maneira exemplar "os óleos inconciliáveis da verdade e da beleza", encontrando o quid que poderia gerar a verdadeira poesia política, por meio da sua incorporação ao modo de ser, e sobretudo, de dizer (CANDIDO, 2004a, p. 24).
\end{abstract}

Aqui Candido formula uma série de questões fundamentais para pensarmos suas ideias. No trecho, temos duas variáveis: política e modo de dizer; e um processo: incorporação. Certas matérias sociais, certos estados da linguagem e da vida prática, como a política, passam por processos diversos de "incorporação" aos "modos de dizer” poéticos. Essa lenta incorporação, para resultar numa boa forma, exigiria um imenso trabalho coletivo de reflexão, erros, acertos, exageros, rotinizações. Dizer bem demandaria incorporar e ter certa paciência com o que não foi bem dito. Dizer bem poeticamente significaria incorporar continuamente os dados e materiais difíceis de dizer. Incorporar sentimentos e temas a uma forma é um trabalho de diversas gerações (noção que Candido não apreciava). Dizer bem, às vezes, cabe a uma só.

Nesse momento de grande efervescência, Candido foi passar as férias em Poços de Caldas. Em São Paulo, seus amigos confabulavam a respeito de criar uma revista sobre vários assuntos (mas ainda não haviam chegado ao nome dela, Clima). Candido recebeu carta informando que fora encarregado da seção de livros. Décio ficou com teatro, Paulo Emílio com cinema, Lourival Gomes Machado com artes, Antonio Branco Lefèvre música, Marcelo Damy de Souza Santos ciências. Como notou Heloísa Pontes, em Destinos mistos, a função na revista definiria a trajetória de cada um dos participantes. Os anos de formação chegavam ao fim. 


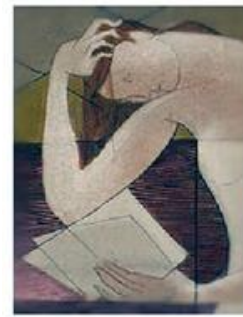

Enquanto isso, em Poços de Caldas, fugido da grande guerra, estava um austríaco chamado Leopold Andrian. Era hábil conversador. Clarisse e Aristides adoravam os assuntos do "Barão", apelido de Andrian. No ano seguinte, o pai de Candido morreria e como tinha sido ele a contatar hotéis para receber Andrian, a família acabou perdendo contato com o austríaco.

Mas dali a uns tempos, lendo um dos volumes de Approximations, de Charles Du Bos, minha mãe encontrou referências a certo poeta do grupo de Hofmannsthal, Leopol Andrian. Chamou a minha atenção e ficamos cismados: coincidência de nome? Logo a seguir li um artigo onde Otto Maria Carpeaux aludia ao mesmo grupo, dizendo que o seu último representante [...] vivia no Rio de Janeiro. Não havia dúvida: era o nosso homem. (CANDIDO, 2004a, p. 259)

O tal barão, que Candido nunca leu, amanhecera como uma estrela literária na Viena fin-de-siècle, um exemplo do "extremado esteticismo decadendista" (idem, p. 260). Ficou para Candido a imagem de um homem bigodudo, com dificuldades para caminhar em razão de uma artrite brava, muito falador e inteligente, cliente hipocondríaco de seu pai.

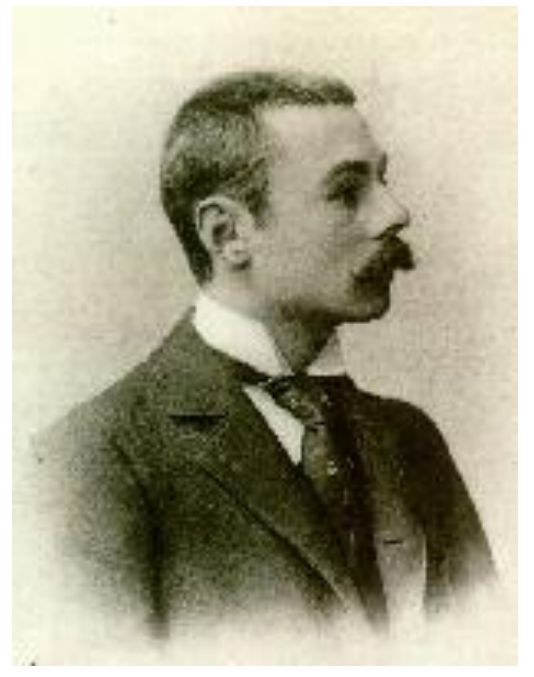

Figura 5 - Fotografia de Andrian e seu bigodão

Andrian vivera um grande furor esteticista na Viena fin-de-siècle e anos depois vivia com pouco dinheiro em hotéis de Poços de Caldas. A descoberta da história é mais uma amostra do tipo de leitura curiosa, atenta, multifacetada que Clarisse empreendia e que parece ter sido fundamental na formação de Antonio Candido.

\section{De chato-boys a militantes}

Clima começa a circular em maio de 1941, por ideia de Alfredo Mesquita. 

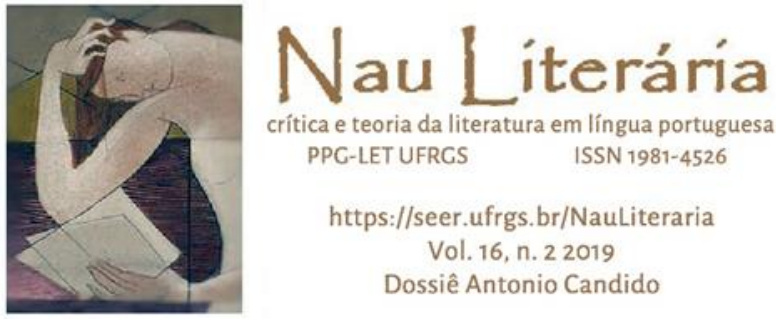

crítica e teoria da literatura em língua portuguesa

PPC-LET UFRCS ISSN 1981-4526

https://seer.ufrgs.br/NauLiteraria

Vol. 16, n. 22019

Dossiê Antonio Candido

A revista era feita um pouco ao léu, no meio da nossa falta de experiência; mas com tanta boa vontade, que foi possível tirá-la mensalmente durante oito números. Ela se ligava à nossa alegre vida de grupo e ia se fazendo como atividade a mais. Nós nos reuníamos quase todas as tardes na Confeitaria Vienense, a antiga, que ficava em frente da atual, mas no andar térreo. Conversávamos, ríamos muito, inventávamos coisas, discutíamos as aulas e os professores, frequentávamos concertos, procurávamos filmes esquecidos em cinemas de bairro, íamos passear em Santo Amaro, o que naquele tempo significava uma excursão fora da cidade. Éramos um grupo alegre, sociável, irreverente, diverso da relativa circunspecção da revista, que no começo teve um ar sério e massudo, provocando em Oswald de Andrade o apelido de chato-boys com que procurou nos caracterizar e nos gozar. (CANDIDO, 2010, p. 143)

Na revista Candido viu outra vez a presença de Jean Maugüe. Para ele, Clima "representou a reflexão de tipo preconizado por Maugüé" (idem, p. 149).

A "reflexão do tipo preconizado por Maugüe" é aquela que o autor de Formação da literatura brasileira desdobraria ao longo da vida, com diversos avanços e recuos, mas com toda persistência: uma composição de análise literária, análise social, teoria literária e reflexão sobre o Brasil, diria Roberto Schwarz. Talvez seja oportuno acrescentar que a reflexão sobre o Brasil é feita na garupa da reflexão sobre a ordem ou desordem mundial capitalista, com suas figuras recorrentes, como o fascismo e o autoritarismo, o roubo e a violência legalizados. Leiam e releiam muito atentamente os textos filosóficos, orientava Maugüe. Dessa leitura atenta deveria surgir problemas sociais amplos, que a própria leitura ajudaria a formular. Ou seja, a leitura atenta de obras literárias passa a ser entendida como uma maneira de mapear os conflitos sociais mais importantes de cada momento, que, caso não sejam "lidos", podem passar sendo sentidos e sofridos, sem ser conscientizados.

Candido considerou que nos primeiros números de Clima ainda estava incipiente a reflexão política e ética. Há nesses números, todavia, muitas coisas. Uma delas, indicada no trecho citado em recuo anteriormente, é a presença viva dos modernistas, Mário e Drummond principalmente; outra é a criação de uma atuante "esfera pública", no sentido de ser um espaço em que os moços testavam ideias e opiniões ainda em formação, arriscando-se um pouco, mas ainda não muito; outra é a prática rotineira de escrever para ser lido. Não sei até onde é correto esse autodiagnóstico feito por Candido de uma relativa alienação política nos primeiros anos, mas pode ter sido a própria atividade de escrever a revista que foi mostrando para os moços da confeitaria - outra esfera pública, parece - a importância de uma crítica ao fascismo, que teria caráter internacional e importava na tomada de posição dos intelectuais fossem de quais áreas 


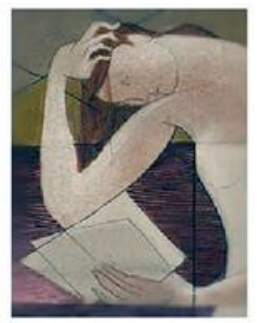

fossem. Os números 11, 12, 13 e 14 da revista, que se contam também como os últimos, apontariam para isso.

Chato-boys, estudiosos, sensatos e sensaborões acabam sendo, por assim dizer, convocados pela ordem do dia (CANDIDO, 2004a, p. 44). Saem da confeitaria para entrar na História, se o mau-gosto do trocadilho não pegar mal.

Nesse período, Candido, o chato-mor, conhece Luis Martins, mas não ficam amigos imediatamente, pois Martins era da turma de Rubem Braga, que acusava os da turma de Candido de serem bem-comportados, "namoram para casar e casam mesmo", sem contar serem bebedores de leite maltado ("na verdade", afirmaria Candido, "bebíamos chá”). Quando Luis Martins foi candidato a vereador pelo Partido Socialista Brasileiro, que Candido ajudou a construir, ambos saíam juntos para colar cartazes São Paulo afora. Nessas ocasiões, Martins expunha sua concepção de socialismo, sempre partindo de uma crítica ao stalinismo e ao centralismo russo (CANDIDO, 2004a, p. 198).

Por volta dos anos 1941, 1942, 1943, Candido dialogava frequentemente com amigos socialistas, que iam se reunindo para formar, em 1945, a União Democrática Socialista. Nesse período, suas memórias auto-acusam um "tosco historicismo" (2004a, p. 189). São frequentes em suas lembranças caminhadas madrugadoras com amigos, pelo centro de São Paulo, de certo meros treinos diante daquela caminhada de $30 \mathrm{~km}$ ao lado de Decio de Almeida Prado.

\begin{abstract}
A UDS (União Democrática Socialista) foi um excelente rebolo, onde afiamos a nossa concepção de socialismo independente de base marxista, convictos de que no processo político transformador cabe posição-chave à classe operária, anti-stalinista sem ser trotskista (o primeiro grupo em São Paulo nessas condições), achando que democracia não é coisa formal e que no Brasil é preciso encontrar soluções adequadas, sem acatar palavras de ordem feitas para outros contextos. Mas a UDS não tinha condições de sobreviver. Por isso, acabamos aderindo à bem menos radical Esquerda Democrática (ED), fundada no Rio em meados de 1945. (CANDIDO, 2004a, p. 208)
\end{abstract}

Em 1947, a ED se transformou em Partido Socialista Brasileiro (PSB). Candido seria um dos responsáveis por publicar a Folha Socialista, órgão do partido para o qual redigiu diversos artigos.

Por essa época, depois de impulsionado pela participação na Clima, era crítico literário de renome, publicando seus artigos e ensaios na Folha da Manhã (1943-45) e no Diário de São Paulo (1945-47).

Antes, porém, de rever as memórias de Candido sobre seus inícios como crítico literário de renome, vale ressaltar um ponto que pesaria nos destinos de todos os participantes da revista. 


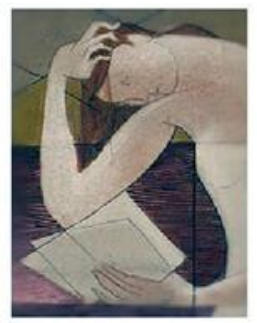

Candido definiu esse ponto como a "presença viva dos modernistas". Mário e Oswald, assim como Drummond, todos mais velhos, eram presença não apenas "espiritual”, mas física nos espaços onde circulavam os moços chatonildos da revista Clima. Estes preferiram acolher a geração anterior, estudá-la com afinco e respeito, lê-la, incentivá-la. Em troca receberam acolhimento parecido, embora Oswald não os tenha poupado de seu sarcasmo habitual. Três exemplos talvez servirão para evocar como se realizava essa "presença viva dos modernistas".

Primeiro exemplo: Mário se correspondeu com Candido a respeito do concurso realizado em 1945, em que Oswald também concorreu.

Segundo exemplo: em 1943, Candido escreveu para Drummond - meio na cara-dura pedindo poemas para publicar na revista Clima. A publicação dos poemas ocorreu um ano depois e eles reapareceram em seguida em A rosa do povo. Em 9 de novembro de 1943, ocorreu um protesto de estudantes contra a ditadura Vargas: um morto e feridos. Candido e uma colega escreveram uma notícia a respeito e enviaram clandestinamente para diversas pessoas, já que a censura impedia a divulgação de tais fatos. Drummond, em seguida, escreveu "O medo" poema dedicado a Candido e utilizando descrições presentes na notícia (CANDIDO, 2004a, p. 25).

Terceiro exemplo: este se passou com Oswald, nos anos 1950, mas será melhor contálo a seguir.

\section{Um poema e o mundo}

Com a intensificação da militância, o início dos trabalhos como professor assistente de sociologia na USP, o trabalho de crítico literário nos jornais, o casamento e a família, o início do doutorado - a princípio sobre o cururu, dança dos caboclos do interior de São Paulo, Goiás e Mato Grosso, mais tarde, sobre os caipiras do interior de São Paulo - e um desejo permanente de se tornar professor de literatura, Antonio Candido estava, por certo, suando a camiseta. Com renome formado, passou a receber cartas de escritores e personalidades. Em 24 de maio de 1944, Otto Maria Carpeaux escreveu para ele enquanto preparava a História da literatura ocidental.

A distinção entre a realidade vivida e a realidade autônoma da arte torna-se mais urgente do que antes. Sei, ou acredito, que o seu ponto de vista sobre tudo isso será bastante diferente do meu. Mas é justamente isso que me leva a perguntar-lhe a sua opinião. Sou um espírito "dialógico", e o diálogo só é fértil quando entre posições dialeticamente opostas. A dialética é a minha obsessão, esforço-me em pensar sempre dialeticamente, 


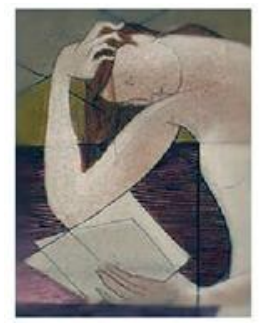

e atribuo a isso muitos dos equívocos aos quais hoje me vejo exposto. (CANDIDO, 2004a, p. 103)

Em meio à militância socialista, Candido percebe nestas palavras, que lhe são críticas, os lineamentos do que ele mesmo vinha elaborando. A autonomia da obra de arte vinha como uma condição de sua eficácia política, fosse qual fosse seu sentido, principalmente o socialista. No seu livro de 1945, o primeiro que publicou, Brigada ligeira, leria Jorge Amado a partir dessa perspectiva: "Documento e poesia se fundem harmoniosamente através do romance histórico" (2004c, p. 45).

A vida estava corrida, movimentada como nunca. O pai falecera em 1942 e as dificuldades aumentaram um pouco. Para complicar, em 1944, circulou o anúncio de um concurso para cadeira de literatura brasileira. Tendo poucos meses para escrever um estudo que lhe serviria para pleitear a vaga ou, como plano b, obter uma livre docência, Candido começou a pensar em um tema. Mário de Andrade lhe sugeriu logo dez e ainda confirmou que não participaria do concurso. Anoto os temas sugeridos por Mário porque ajudam a pensar, desde a perspectiva do próprio Mário o leque de questões disponíveis a um jovem acadêmico nos anos 1945 (cf.CANDIDO, 2004a, p. 261 e ss.):

- Graça Aranha; Alcântara Machado (o senador); Amadeu Amaral; Vicente de Carvalho (todos estes escolhidos porque eram assuntos "quase virgens" a respeito dos quais Candido teria facilmente acesso à “documentação inédita de arquivos particulares”);

- Relações entre a Ideia e o Verso no Parnasianismo (“estudar por exemplo, todos os transbordamentos [enjambement])";

- A composição no Romance Brasileiro do Século XIX ("talvez um bocado sutil demais para uma banca de acadêmicos");

- O Rural e o Urbano no Romance (Poesia) do Século XIX; O Realismo; A Imposição da cidade;

- O Subjetivismo na Descrição Romântica da Natureza;

- Evolução na Ideia de ......... na Poesia Brasileira Contemporânea (Ideia de pátria, por exemplo);

- Psicologia do Português (do africano, do índio, do estrangeiro, do mestiço) no Romance Brasileiro do Século XIX. 


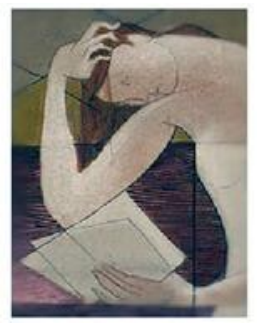

Candido deixou todos os bons temas para lá e se dedicou por dez meses a escrever um estudo sobre um assunto que lhe parecia "familiar" e lhe dava segurança: "Era, para mim, o caso de Sílvio Romero, cujos livros li na biblioteca de meu pai desde menino. Decidi por ele e em cerca de dez meses mal-amanhei um trabalho sobre o seu método crítico" (2004a, p. 264).

A lista de Mário não foi todavia abandonada. Preocupações ali postas, decerto presentes também em outras correspondências e conversas, ecoariam em diversos escritos de Candido: a composição no romance, indicada num dos temas, firmou-se, sob sinônimos como "plano", um dos principais critérios estéticos em diversas críticas publicadas em jornais de São Paulo no período. Já a xenofobia do romance brasileiro, que Mário comenta ao desdobrar a última sugestão - sobre a psicologia - reapareceria em um dos principais estudos de Candido, "De cortiço a cortiço".

Embora Mário tenha preferido não participar do concurso, Oswald de Andrade participou. Candido e Oswald não foram indicados, e Souza Lima acabou aprovado. Os dois porém ficaram livre-docentes.

Embora professor assistente de sociologia, Candido era cada vez mais reconhecido como crítico literário. Por volta de 1947, 48, lembra que ocorreu o seguinte:

\begin{abstract}
Eu andava numa fase de grande interesse pelas literaturas de língua inglesa, escrevendo e palestrando sobre Eliot, descobrindo Joseph Conrad, lendo as obras do "grupo de Oxford", debulhando Ezra Pound e me iniciando na crítica de Eliot, Leavis, Empson e do New Criticism americano, que descobri por acaso num ensaio relevador de Cleanth Brooks, "The Poema as an Organism", incluído em livro coletivo, o English Institute Annual, da Universidade de Colúmbia, que Mário de Andrade me deu ali por 1943. (CANDIDO, 2010, p. 193)
\end{abstract}

Seu amigo e correspondente, Richard M. Morse, enviou trabalhos de Blackmur e John Crowe Ransom, como The New Criticism, e presenteou-lhe com uma assinatura da Hudson Review. As discussões presentes nessas publicações ajudaram Candido a construir uma ideia de "concreto" a partir do texto literário, dando-lhe um fundo de autoridade teórica para sustentar uma atenção cuidadosa ao texto literário e suas estruturas.

Morse publicou $O$ espelho de Próspero: cultura e ideias na América, que, em 1988, teve tradução prefaciada por Candido. O diálogo com Morse pode ter sido fundamental para a hipótese de "Dialética da malandragem" (1970), em que a civilização malandra não entra com desvantagem frente aos regramentos militares e europeus, pelo contrário. Essa hipótese assinala 


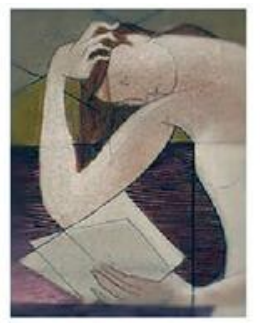

uma modificação qualitativa nas reflexões de Candido, que tendia até então a enfatizar a discrepância para pior das culturas no Brasil em relação às obras das civilizações europeias.

Por volta de meados de 1940, Roger Bastide o aconselhou a migrar da área da sociologia para a da literatura. O sociólogo considerava que Candido estava mais bem armado para esta segunda tarefa. O diálogo entre os dois porém foi além desses aconselhamentos. Nos artigos que Bastide escreve sobre cultura, principalmente em torno das questões relativas à raça e literatura, Candido percebe mais nitidamente como formular a lenta e quase imperceptível incorporação de dilemas sociais à forma artística.

No longo aprendizado que, a bem dizer, iniciou com o século, quando Aristides comprou Os sertões, Candido definiu alguns princípios. Era preciso ler, com carinho e apreço, o texto em sua autonomia, como mundo de formas e sentidos. Valia, para isso, variar o método, conforme fosse o caso e a exigência que cada análise de texto fosse colocando. Nada deveria ser descartado de antemão, mas métodos ou conceitos abstratos, fossem quais fossem, precisavam ser exigidos pelo texto literário. Por último e mais importante, caberia, em toda análise estética, verificar a penetração lenta da matéria social nas formas estéticas.

Em tudo isso, é preciso sempre ter em mente que a instrução popular é questão fundamental para o socialismo. Democratizar os bens culturais, sejam quais forem, é uma luta de primeira importância. E, portanto, a crítica literária deve estar a serviço da democratização da cultura. Para isso, seria necessário incorporar à reflexão os estudos brasileiros sobre diversos assuntos, fazendo-os render, como diria Roberto Schwarz, em campo que não lhes era próprio. Como princípio anexo a esse, estava a concepção de que haveria continuidades entre populismo e fascismo, inclusive no pós-guerra, o que implicava, do ponto de vista socialista, a necessidade de lançar as bases para uma radicalização das classes médias.

Assim, talvez não seja exagero dizer que o crítico literário que inscreveu na linguagem da teoria da literatura as palavras fome, subdesenvolvimento, censura e violência, apareceu no momento em que se formou o militante socialista.

Melhor do que encerrar esta narrativa com uma síntese tão abstrata e árida, será encerrála com dois episódios. Começo com o terceiro exemplo da presença viva dos modernistas, que havia deixado em espera.

Por volta de 1950, Oswáld foi à casa de Candido e Gilda, no encontro de Aclimatação, Cambuci e Glória. "Na saída", conta Candido, 


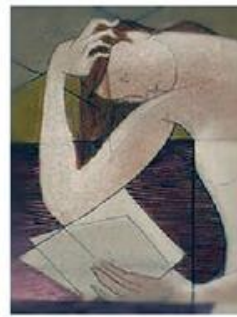

eu o acompanhei, para ajudá-lo a pegar um táxi. Atravessamos a rua Pires da Mota e entramos na Conselheiro Furtado. Era uma tarde fresca, azul e sossegada, como ainda havia naquele tempo. Ouvindo, eu olhava o renque de casinhas baixas, encardidas. E de repente me pareceu estar numa rua de romance dele, Condenados ou Estrela de absinto, vagando na ficção junto com o autor, que seria ao mesmo tempo um dos seus personagens. Foi apenas um segundo, durante o qual senti sem poder explicar que estávamos ambos no mundo da sua narrativa. Mas não disse nada. O táxi passou, ele subiu e foi embora. A sensação permanceu em mim como lembrança, e estou certo de que, no leitor interessado apenas em fruir, permanecerá também a sensação de ter penetrado na atmosfera fechada e aberta da garçonnière, que o diário de bordo construiu acima do tempo. (CANDIDO, 2004a, p. 54)

A garçonnière é um refúgio cerrado e um eco do mundo, assim como teria sido a biblioteca de seus pais e assim como poderia ser a própria literatura para Candido.

Um refúgio, mas também uma trincheira de ataque. Em 1964, aulas dadas por Candido na USP diziam respeito à análise de um poema de Emílio Moura. Candido já o sabia de cor e o declamava.

"Permanência da Poesia"

Quando a luz desaparecer de todo,

mergulharei em mim mesmo e te procurarei lá dentro.

A beleza é eterna.

A poesia é eterna.

A liberdade é eterna.

Elas subsistem, apesar de tudo.

É inútil assassinar crianças. É inútil atirar aos cães os que, de repente, se rebelam e erguem a [cabeça olímpica.

A beleza é eterna. A poesia é eterna. A liberdade é eterna.

Podem exilar a poesia: exilada, ainda será mais límpida.

As horas passam, os homens caem,

a poesia fica.

Aproxima-te e escuta.

Há uma voz na noite!

Olha:

É uma luz na noite! (MOURA, 2002, p. 173)

Os dias que vivemos obrigam a guardar esse poema - e a resguardar, no fundo dele, a voz viva de Antonio Candido.

\section{Agradecimentos}



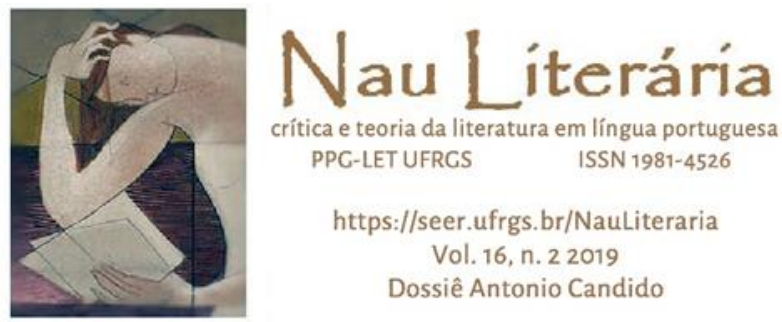

Este ensaio é resultado do desdobramento de anotações de aulas para um curso de graduação sobre a obra de Antonio Candido que ministrei em 2018 na Universidade Federal do Ceará. Agradeço às/aos estudantes da disciplina as interrogações e as profundas leituras que partilharam comigo, especialmente Karina Morais, Luane Mota, Rinaldo Vianna e Wesley Lucas Batista da Silva. Agradeço a Adelaide Gonçalves, Irenísia Oliveira, Regina Zilberman, Suene Honorato e Vitor Necchi por terem ou lido, ou comentado, ou discutido este ensaio e ideias nele presentes, desde quando eram anotações de aula.

\section{Referências}

ESCOREL, Ana Luisa. O pai, a mãe e a filha. Rio de Janeiro: Ouro sobre Azul, 2010. CANDIDO, Antonio. Tese e antítese: estudos. São Paulo: Cia. Editora Nacional, 1964. . Rascunho para depoimento à UBE. Texto digitalizado. Mimeo. 1984. Na sala de aula: caderno de análise literária. São Paulo: Ática, 1985. . Os parceiros do Rio Bonito: estudo sobre o caipira paulista e a transformação dos seus meios de vida. São Paulo: Duas Cidades, Ed. 34, 2001. . Recortes. Rio de Janeiro: Ouro sobre Azul, 2004a. Vários escritos. Rio de Janeiro: Ouro sobre Azul, 2004b. . Brigada ligeira. Rio de Janeiro: Ouro sobre Azul, 2004c. . Teresina etc. Rio de Janeiro: Ouro sobre Azul, 2007a. . Um funcionário da monarquia: ensaio sobre o segundo escalão. Rio de Janeiro: Ouro sobre Azul, 2007b. O observador literário. Rio de Janeiro: Ouro sobre Azul, 2008. O albatroz e o chinês. Rio de Janeiro: Ouro sobre Azul, 2010.

Conversa cortada: a correspondência entre Antonio Candido e Ángel Rama (1960-1983). Edição, prólogo e notas: Pablo Rocca. Tradução de Ernani Ssó. Rio de Janeiro, São Paulo: Ouro Sobre Azul, Edusp, 2018.

REMATE DE MALES. Departamento de Teoria Literária IEL/Unicamp. Número especial Antonio Candido. Campinas, 1999.

ESCOLA NACIONAL FLORESTAN FERNANDES. Cadernos de Estudos ENFF: Literatura e formação da consciência. São Paulo, 2007.

"A dialética da malandragem". In $O$ discurso e a cidade. Rio de Janeiro: Ouro sobre Azul, 2004a.

"De cortiço a cortiço". In O discurso e a cidade. Rio de Janeiro: Ouro sobre Azul, 2004b.

MORSE, Richard. O espelho de Próspero: cultura e ideias na América. Tradução de Paulo Neves. São Paulo: Cia. das Letras, 1988.

MELLO E SOUZA, Gilda de. A ideia e o figurado. São Paulo: Duas Cidades, Ed. 34: 2005.

MELLO E SOUZA, Roberto. Mina R: narrativa. Rio de Janeiro: Record, 1995.

MOURA, Emílio. Itinerário poético: poemas reunidos. Prefácio de Carlos Drummond de Andrade. Belo Horizonte: UFMG, 2002. 


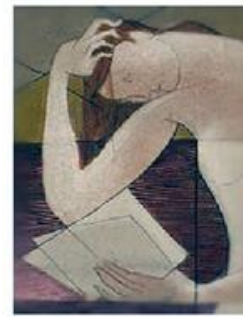

PIGLIA, Ricardo. Formas breves. Tradução José Marcos Mariani de Macedo. São Paulo: Cia. das Letras, 2004.

PONTES, Heloísa. Destinos mistos: os críticos do grupo Clima em São Paulo (1940-1968). São Paulo: Cia. das Letras, 1998.

PRADO JÚNIOR, Caio. Evolução política do Brasil e outros estudos. São Paulo: Cia. das Letras, 2012.

ROCHA, Fernando Côrrea. Cartas de um piloto de caça: o treinamento e o combate (19431945). Organização Heloísa Rocha Pires. Prefácio de Antonio Candido. Rio de Janeiro: Ouro sobre Azul, 2012.

\section{Fontes das figuras}

Figura 1: The Metropolitam Museum of Art. Disponível em https://www.mhttps://www.metmuseum.org/toah/works-ofart/11.173.3/etmuseum.org/toah/works-of-art/11.173.3/ Acessado em 01/02/2020.

Figura 2 : Disponível em http://www.conradoleiloeiro.com.br/catalogo.asp?Num=2507\&Dia=2\&p=on. Acessado em 01/02/2020.

Figuras 3 e 4: Correio Paulistano, 1938 e 1939. Disponível em https://bndigital.bn.gov.br/acervodigital. Acessado em 01/02/2020.

Figura 5: Disponível em https://en.wikipedia.org/wiki/Leopold_Andrian. Acessada em 01/02/2020. 